medRxiv preprint doi: https://doi.org/10.1101/2020.07.27.20161810; this version posted July 29, 2020. The copyright holder for this preprint

(which was not certified by peer review) is the author/funder, who has granted medRxiv a license to display the preprint in perpetuity.

This article is a US Government work. It is not subject to copyright under 17 USC 105 and is also made available for use under a CCO license.

\title{
Risk Factors for COVID-19-associated hospitalization: COVID-19-Associated Hospitalization Surveillance Network and Behavioral Risk Factor Surveillance System
}

Jean Y. Ko ${ }^{1,2}$, Melissa L. Danielson ${ }^{1}$, Machell Town ${ }^{3}$, Gordana Derado ${ }^{1}$, Kurt J. Greenlund ${ }^{3}$, Pam Daily Kirley ${ }^{4}$, Nisha B. Alden ${ }^{5}$, Kimberly Yousey-Hindes ${ }^{6}$, Evan J. Anderson ${ }^{7,8,9}$, Patricia A. Ryan $^{10}$, Sue Kim ${ }^{11}$, Ruth Lynfield ${ }^{12}$, Salina M. Torres ${ }^{13}$, Grant R. Barney ${ }^{14}$, Nancy M. Bennett $^{15}$, Melissa Sutton ${ }^{16}$, H. Keipp Talbot ${ }^{17}$, Mary Hill ${ }^{18}$, Aron J. Hall ${ }^{1}$, Alicia M. Fry ${ }^{1,2}$, Shikha Garg ${ }^{1,2}$, Lindsay Kim ${ }^{1,2}$, COVID-NET Investigation Group

\section{Affiliations:}

${ }^{1}$ CDC COVID-NET Team, Atlanta, GA, USA

${ }^{2}$ US Public Health Service, Rockville, MD, USA

${ }^{3}$ Division of Population Health, National Center for Chronic Disease Prevention and Health Promotion, CDC

${ }^{4}$ California Emerging Infections Program, Oakland, CA

${ }^{5}$ Colorado Department of Public Health and Environment, Denver, CO

${ }^{6}$ Connecticut Emerging Infections Program, Yale School of Public Health, New Haven, CT

${ }^{7}$ Departments of Medicine and Pediatrics, Emory University School of Medicine, Atlanta, GA

${ }^{8}$ Emerging Infections Program, Georgia Department of Health, Atlanta, GA

${ }^{9}$ Veterans Affairs Medical Center, Atlanta, GA

${ }^{10}$ Maryland Department of Health, Baltimore, MD

${ }^{11}$ Michigan Department of Health and Human Services, Lansing, MI

${ }^{12}$ Minnesota Department of Health, St. Paul, MN

${ }^{13}$ New Mexico Department of Health, Santa Fe, NM

${ }^{14}$ New York State Department of Health, Albany, NY

${ }^{15}$ University of Rochester School of Medicine and Dentistry, Rochester, NY 
medRxiv preprint doi: https://doi.org/10.1101/2020.07.27.20161810; this version posted July 29, 2020. The copyright holder for this preprint

(which was not certified by peer review) is the author/funder, who has granted medRxiv a license to display the preprint in perpetuity.

This article is a US Government work. It is not subject to copyright under 17 USC 105 and is also made available for use under a CCO license.

${ }^{16}$ Oregon Health Authority, Portland, OR

${ }^{17}$ Vanderbilt University School of Medicine, Nashville, TN

${ }^{18}$ Salt Lake County Health Department, Salt Lake City, UT

\section{For the COVID-NET Investigation Group:}

Michael Whitaker (CDC COVID-NET, Eagle Global Scientific, Atlanta, GA, USA); Alissa

O’Halloran (CDC COVID-NET); Rachel Holstein (CDC COVID-NET, Oak Ridge Institute for

Science and Education); William Garvin (CDC Division of Population Health); Shua J. Chai

(California Emerging Infections Program, Oakland, CA, Career Epidemiology Field Officer,

CDC/CPR/DSLR); Breanna Kawasaki (Colorado Department of Public Health and Environment,

Denver, CO); James Meek (Connecticut Emerging Infections Program, Yale School of Public

Health, New Haven CT); Kyle P. Openo (Emerging Infections Program, Georgia Department of

Health, Atlanta, GA, Veterans Affairs Medical Center, Atlanta, GA, Foundation for Atlanta

Veterans Education and Research, Decatur, GA); Maya L. Monroe (Maryland Department of

Health, Baltimore, MD); Justin Henderson (Michigan Department of Health and Human

Services, Lansing, MI); Kathy Como-Sabetti (Minnesota Department of Health, St. Paul, MN);

Sarah Shrum Davis (New Mexico Department of Health, Santa Fe, NM); Nancy L. Spina (New

York State Department of Health, Albany, NY); Christina B. Felsen (University of Rochester

School of Medicine and Dentistry, Rochester, NY); Nicole West (Oregon Health Authority,

Portland, OR); William Schaffner (Vanderbilt University School of Medicine, Nashville, TN);

Andrea George (Salt Lake County Health Department, Salt Lake City, UT)

Running Title: Risk Factors for COVID-19-associated hospitalizations

Manuscript Word Count: 3,483 
medRxiv preprint doi: https://doi.org/10.1101/2020.07.27.20161810; this version posted July 29, 2020. The copyright holder for this preprint

(which was not certified by peer review) is the author/funder, who has granted medRxiv a license to display the preprint in perpetuity.

This article is a US Government work. It is not subject to copyright under 17 USC 105 and is also made available for use under a CCO license.

\section{ABSTRACT}

Background: Identification of risk factors for COVID-19-associated hospitalization is needed to guide prevention and clinical care.

Objective: To examine if age, sex, race/ethnicity, and underlying medical conditions is independently associated with COVID-19-associated hospitalizations.

Design: Cross-sectional.

Setting: 70 counties within 12 states participating in the Coronavirus Disease 2019-Associated Hospitalization Surveillance Network (COVID-NET) and a population-based sample of nonhospitalized adults residing in the COVID-NET catchment area from the Behavioral Risk Factor Surveillance System.

Participants: U.S. community-dwelling adults ( $\geq 18$ years) with laboratory-confirmed COVID19-associated hospitalizations, March 1- June 23, 2020.

Measurements: Adjusted rate ratios (aRR) of hospitalization by age, sex, race/ethnicity and underlying medical conditions (hypertension, coronary artery disease, history of stroke, diabetes, obesity $\left[\mathrm{BMI} \geq 30 \mathrm{~kg} / \mathrm{m}^{2}\right]$, severe obesity $\left[\mathrm{BMI} \geq 40 \mathrm{~kg} / \mathrm{m}^{2}\right]$, chronic kidney disease, asthma, and chronic obstructive pulmonary disease).

Results: Our sample included 5,416 adults with COVID-19-associated hospitalizations. Adults with (versus without) severe obesity (aRR:4.4; 95\%CI: 3.4, 5.7), chronic kidney disease (aRR:4.0; 95\%CI: 3.0, 5.2), diabetes (aRR:3.2; 95\%CI: 2.5, 4.1), obesity (aRR:2.9; 95\%CI: 2.3, 3.5), hypertension (aRR:2.8; 95\%CI: 2.3, 3.4), and asthma (aRR:1.4; 95\%CI: 1.1, 1.7) had higher rates of hospitalization, after adjusting for age, sex, and race/ethnicity. In models adjusting for the presence of an individual underlying medical condition, higher hospitalization rates were observed for adults $\geq 65$ years, 45-64 years (versus 18-44 years), males (versus females), and non-Hispanic black and other race/ethnicities (versus non-Hispanic whites). 
medRxiv preprint doi: https://doi.org/10.1101/2020.07.27.20161810; this version posted July 29, 2020. The copyright holder for this preprint

(which was not certified by peer review) is the author/funder, who has granted medRxiv a license to display the preprint in perpetuity.

This article is a US Government work. It is not subject to copyright under 17 USC 105 and is also made available for use under a CCO license.

Limitations: Interim analysis limited to hospitalizations with underlying medical condition data.

Conclusion: Our findings elucidate groups with higher hospitalization risk that may benefit from targeted preventive and therapeutic interventions. 
medRxiv preprint doi: https://doi.org/10.1101/2020.07.27.20161810; this version posted July 29, 2020. The copyright holder for this preprint

(which was not certified by peer review) is the author/funder, who has granted medRxiv a license to display the preprint in perpetuity.

This article is a US Government work. It is not subject to copyright under 17 USC 105 and is also made available for use under a CCO license.

\section{INTRODUCTION}

As of June 26, 2020, over 9 million cases of Coronavirus Disease 2019 (COVID-19), the disease caused by SARS-CoV-2, have been reported worldwide (1); over 2 million cases, including $>120,000$ deaths, have been reported in the United States (2). Older age and underlying medical conditions are prevalent among cases $(3,4,5,6,7,8,9,10,11,12,13)$. Based on preliminary estimates, approximately $30 \%$ of U.S. laboratory-confirmed COVID-19 cases were among adults aged $\geq 65$ years $(7,8)$ and about one third had underlying medical conditions (9). Among U.S. hospitalized cases, diabetes mellitus (8, 9, 10, 11, 12, 13, 14), hypertension (10, 11, $12,13,14)$, cardiovascular disease $(8,9,10,14)$ obesity $(10,11,13,14)$, and chronic lung disease $(8,9,10)$ were common. However, the risk of hospitalization imparted by underlying medical conditions is not clear; many of these conditions, e.g., obesity (15), hypertension (16), and diabetes (17), are also prevalent in the general U.S. population.

Similarly, the risk of hospitalization related to sex and race/ethnicity is unclear. An estimated $60 \%$ of New York patients hospitalized for COVID-19 were male (11); however, other studies have found the male-female distribution among COVID-19 hospitalizations to be similar to the general U.S. population $(50 \%)(10,18)$. Non-Hispanic black adults comprised a greater proportion of hospitalized COVID-19 cases compared to the community population in 14 states (10) and to overall hospitalizations in Georgia (18).

Two studies of communities served by single health care systems in Louisiana (19) and in New York City and Long Island (20) assessed the independent risk for hospitalization among adults who tested positive for SARS-CoV-2 (19, 20); however these studies did not account for the underlying distribution of age, sex, race/ethnicity and underlying medical conditions in these communities.

To better understand the independent association of age, sex, race/ethnicity, and underlying medical conditions with COVID-19-associated hospitalization relative to the non- 
medRxiv preprint doi: https://doi.org/10.1101/2020.07.27.20161810; this version posted July 29, 2020. The copyright holder for this preprint

(which was not certified by peer review) is the author/funder, who has granted medRxiv a license to display the preprint in perpetuity.

This article is a US Government work. It is not subject to copyright under 17 USC 105 and is also made available for use under a CCO license.

hospitalized community-dwelling population, we calculated rate ratios for adults with and without select underlying medical conditions, adjusted for age, sex, and race/ethnicity, using data from the Coronavirus Disease 2019-Associated Hospitalization Surveillance Network (COVIDNET) and the Behavioral Risk Factor Surveillance System (BRFSS), two large multi-state surveillance systems.

\section{METHODS}

\section{Surveillance data sources and definition of cases}

COVID-NET is an all age population-based surveillance system of laboratory-confirmed COVID-19-associated hospitalizations. To be included as a case, patients must have a positive SARS-CoV-2 test no more than 14 days before admission or during hospitalization; be a resident of the pre-identified surveillance catchment area; and be admitted to a hospital where residents of the surveillance catchment area receive care. Medical chart abstractions using a standard case report form are performed by trained surveillance officers to collect additional data such as patient demographics, underlying medical conditions, clinical course, and outcomes data. Additional COVID-NET details are described elsewhere (10, 21). This study includes 70 counties in 12 participating states (California, Colorado, Connecticut, Georgia, Maryland, Michigan, Minnesota, New Mexico, New York, Oregon, Tennessee, and Utah).

The BRFSS is a nationwide cross-sectional telephone survey that collects state-based data on health-related risk behaviors, chronic health conditions, and use of preventive services from more than 400,000 community-dwelling adults ( $\geq 18$ years) each year (22). The BRFSS was used to provide estimates of the non-hospitalized population in the 70 COVID-NET counties included in this study, herein referred to as the COVID-NET catchment area. The percentage of adults with the select underlying medical conditions of interest by demographic subgroup (sex, age group, race/ethnicity group) were calculated from BRFSS respondents residing in the 
medRxiv preprint doi: https://doi.org/10.1101/2020.07.27.20161810; this version posted July 29, 2020. The copyright holder for this preprint

(which was not certified by peer review) is the author/funder, who has granted medRxiv a license to display the preprint in perpetuity.

This article is a US Government work. It is not subject to copyright under 17 USC 105 and is also made available for use under a CCO license.

COVID-NET catchment area. These responses were then weighted to the total population at risk for hospitalization residing in the catchment area using an iterative proportional fitting method, which includes categories of age by gender, race and ethnicity groups, education levels, marital status, regions within states, gender by race and ethnicity, telephone source, renter or owner status, and age groups by race and ethnicity to improve the degree and extent to which the BRFSS sample properly reflects the sociodemographic make-up of our geographic area of interest (22). Weights also accounted for survey design, probability of selection, nonresponse bias, and non-coverage error (22). To understand if the prevalence of underlying medical conditions in the COVID-NET catchment area was different from national estimates, nationwide BRFSS data were used. All weighted population estimates were calculated using 2018 BRFSS data for each characteristic and underlying medical condition except hypertension; 2017 was the most recent year of available BRFSS data that included hypertension questions.

To match the population captured by BRFSS, this analysis was restricted to communitydwelling adults ( $\geq 18$ years) residing in the 70 COVID-NET counties in 12 states with available data on underlying medical conditions (Figure 1). As of June 23, 2020, there were a total of 5,715 adult COVID-19-associated hospitalizations eligible for inclusion in our analysis; 5,416 adults had underlying medical condition data and composed the analytic population for this study.

\section{Variable definitions}

In COVID-NET, the presence of underlying medical conditions was ascertained if the condition (hypertension; history of myocardial infarction, coronary artery disease, coronary artery bypass grafting; stroke; diabetes mellitus; chronic kidney disease; asthma; chronic obstructive pulmonary disease [COPD]) was present in the patient's medical chart that detailed their COVID-19-associated hospitalization. In BRFSS, underlying medical conditions were 
medRxiv preprint doi: https://doi.org/10.1101/2020.07.27.20161810; this version posted July 29, 2020. The copyright holder for this preprint

(which was not certified by peer review) is the author/funder, who has granted medRxiv a license to display the preprint in perpetuity.

This article is a US Government work. It is not subject to copyright under 17 USC 105 and is also made available for use under a CCO license.

based on self-report to the question: "Has a doctor, nurse, or other health professional ever told you that you had..." (high blood pressure; heart attack also called myocardial infarction, angina or coronary heart disease; stroke; diabetes, chronic kidney disease; asthma; COPD, emphysema, or chronic bronchitis).

Histories of myocardial infarction, coronary artery disease, and coronary artery bypass grafting (only available in COVID-NET) were categorized as coronary artery disease. In BRFSS, adults who self-reported having high blood pressure and answered "yes" to the subsequent question "are you currently taking medication for your high blood pressure?" were categorized as having hypertension. In COVID-NET data, body mass index (BMI) was calculated using height and weight listed in medical charts; if these data were not available, recorded BMI was used. In BRFSS, self-reported height and weight were used to calculate BMI. BMI was then categorized as obese $\left(\geq 30 \mathrm{~kg} / \mathrm{m}^{2}\right)$ or severely obese $\left(\geq 40 \mathrm{~kg} / \mathrm{m}^{2}\right)$.

For both COVID-NET and BRFSS data, we created an "any condition" variable (which included presence of history of coronary artery disease; stroke; diabetes; obesity; severe obesity; chronic kidney disease; asthma; COPD) and "number of conditions" variable $(0 ; 1 ; 2 ; 3+)$. Hypertension was not included in the "any condition" or "number of conditions" variables because COVID-NET catchment estimates for hypertension were derived from 2017 BRFSS estimates and could not be integrated with the other 2018 estimates of underlying medical conditions. Although hypertension is not included in these composite variables, in $2017,14 \%$ of adults with treated hypertension also had at least one other underlying medical condition examined in this analysis. Additional details are available in Supplemental Table 1. The following categories were defined for age (18-44; 45-64; $\geq 65$ years), sex (male; female), and race/ethnicity (non-Hispanic white; non-Hispanic black; other). Other races and ethnicities besides non-Hispanic white and non-Hispanic were aggregated due to small cell sizes from the 
medRxiv preprint doi: https://doi.org/10.1101/2020.07.27.20161810; this version posted July 29, 2020. The copyright holder for this preprint

(which was not certified by peer review) is the author/funder, who has granted medRxiv a license to display the preprint in perpetuity.

This article is a US Government work. It is not subject to copyright under 17 USC 105 and is also made available for use under a CCO license.

COVID-NET catchment area once these data were stratified by age, sex and underlying medical conditions.

\section{Statistical analysis}

Demographic characteristics were tabulated among hospitalized COVID-19 cases overall and by underlying medical condition. The prevalence of select underlying medical conditions was calculated among COVID-19-associated hospitalizations, the COVID-NET catchment area, and nationwide. Unadjusted rate ratios were calculated to compare the relative rates of hospitalization by demographic subgroup or presence of each underlying medical condition. The numerator for each rate was the number of hospitalized adults in each demographic subgroup with or without each underlying medical condition estimated from COVID-NET. The denominator for each rate was the number of adults in each demographic subgroup with or without each underlying medical condition derived from BRFSS estimates for the COVID-NET catchment area. Generalized Poisson regression models with a scaled deviance term to account for overdispersion were used to calculate unadjusted and adjusted rate ratios and $95 \%$ confidence intervals (CIs) associated with hospitalization. Multivariable models included an individual underlying medical condition, age, sex, and race/ethnicity. Model goodness of fit was assessed by evaluating standardized deviance residual plots. Rate ratios with 95\% CIs that excluded 1 were considered statistically significant. We also assessed the prevalence of co-occurring conditions in hospitalized cases (Supplemental Table 2); however, due to the analytic design of this study and small cell counts of BRFSS estimates from the COVID-NET catchment area, we were unable to account for combinations of underlying medical conditions in our adjusted models. Weighted population estimates from BRFSS were calculated using SAS-callable SUDAAN. All other analyses were performed using SAS v.9.4 (SAS Institute, Cary, NC). No personal identifiers were included in either COVID-NET or BRFSS data submitted to CDC. This analysis was exempt from CDC's Institutional Review Board, as it was considered 
medRxiv preprint doi: https://doi.org/10.1101/2020.07.27.20161810; this version posted July 29, 2020. The copyright holder for this preprint

(which was not certified by peer review) is the author/funder, who has granted medRxiv a license to display the preprint in perpetuity.

This article is a US Government work. It is not subject to copyright under 17 USC 105 and is also made available for use under a CCO license.

part of public health surveillance and emergency response. Participating sites obtained approval for the COVID-NET surveillance protocol from their respective state and local IRBs, as required.

\section{RESULTS}

Of 5,416 community-dwelling adults with COVID-19-associated hospitalization, 30\% were aged 18-44 years, $40 \%$ were aged $45-64$ years and $31 \%$ were aged $65+$ years; $53 \%$ were male; 34\% were non-Hispanic White, $32 \%$ were non-Hispanic Black and 34\% were of other races/ethnicities (Table 1). Overall, 55\% had obesity, 49\% had hypertension, 33\% had diabetes, $16 \%$ had severe obesity, $13 \%$ had asthma, $12 \%$ had chronic kidney disease, $9 \%$ had a history of coronary artery disease, $6 \%$ had COPD, and $4 \%$ had a history of stroke. Excluding hypertension, $73 \%$ of hospitalized cases had at least one underlying medical condition. Co-occurring underlying medical conditions were common among hospitalized cases (e.g., most adults with coronary artery disease, stroke, diabetes, chronic kidney disease, or COPD also had hypertension) (Supplemental Table 2).

Among hospitalized cases, the prevalence of underlying medical conditions was greatest among adults aged 65+ years except for obesity, severe obesity, and asthma (Table 1). The prevalence of obesity (63\%) and severe obesity (25\%) was greatest among adults aged 18-44 years. The prevalence of asthma was similar across all age groups. Males and females had similar prevalences of history of stroke, diabetes, and COPD. The prevalence of underlying medical conditions was highest among non-Hispanic black adults, except for coronary artery disease and COPD.

The overall prevalence of selected underlying medical conditions was greater among hospitalized cases compared to the COVID-NET catchment area population (Figure 2). COVIDNET catchment area estimates were similar or slightly lower than nationwide estimates: 
medRxiv preprint doi: https://doi.org/10.1101/2020.07.27.20161810; this version posted July 29, 2020. The copyright holder for this preprint

(which was not certified by peer review) is the author/funder, who has granted medRxiv a license to display the preprint in perpetuity.

This article is a US Government work. It is not subject to copyright under 17 USC 105 and is also made available for use under a CCO license.

hypertension (21\% vs. $25 \%)$, coronary artery disease (5\% vs. $7 \%$ ), history of stroke (3\% vs.

$3 \%$ ), diabetes (9\% vs. $11 \%$ ), obesity ( $28 \%$ vs. $31 \%$ ), severe obesity (4\% vs $5 \%$ ), chronic kidney disease (2\% vs. $3 \%)$, asthma (10\% vs. $9 \%)$, and COPD (5\% vs. $7 \%)$.

Unadjusted rate ratios for COVID-19-associated hospitalizations of adults 45-64 years of age and 65 years and older, versus 18-44 years, were 2.0 (95\%CI: 1.8, 2.1) and 2.7 (95\% CI: 2.5, 2.9), respectively (Table 2). The unadjusted rate ratio for hospitalization comparing males to females was 1.2 (95\%CI: 1.1, 1.3) and for non-Hispanic black to non-Hispanic white adults was 3.9 (95\%CI: 3.7, 4.2). Adults with, versus without, specified underlying medical conditions had higher rates of hospitalization; unadjusted rate ratios ranged from $1.2(95 \% \mathrm{CI}: 0.4,3.8)$ for COPD to 5.3 (95\%CI: 2.4, 12.1) for chronic kidney disease.

The rate ratios for underlying medical conditions attenuated after adjustment for age, sex, and race/ethnicity; except for the rate ratios for severe obesity and asthma which remained stable (Table 2). In descending order of magnitude, the adjusted rate ratios (aRR) for hospitalization by underlying medical condition were as follows: severe obesity (aRR:4.4; 95\%CI: 3.4, 5.7), chronic kidney disease (aRR:4.0; 95\%CI: 3.0, 5.2), diabetes (aRR:3.2; 95\%CI: 2.5, 4.1), obesity (aRR:2.9; 95\%CI: 2.3, 3.5), hypertension (aRR:2.8; 95\%CI: 2.3, 3.4), asthma (aRR:1.4; 95\%CI: 1.1, 1.7), coronary artery disease (aRR:1.3; 95\%CI:0.99, 1.8), COPD (aRR: 0.9; 95\%CI: 0.7, 1.4), stroke (aRR: 0.9; 95\%CI: 0.6, 1.4) (Table 2; Figure 3). After adjustment for age, sex, and race/ethnicity, rate ratios for hospitalization increased with the number of conditions (versus no conditions), with the greatest rate ratio for adults with $3+$ conditions (aRR: 5.0; 95\%CI:3.9, 6.3) (Supplemental Table 3).

Across individual underlying medical condition models, the adjusted rate ratio of hospitalization was significantly higher for adults $\geq 65$ years and $45-64$ years (versus $18-44$ years), males (versus females), and non-Hispanic black and other race/ethnicities (versus nonHispanic whites) (Table 2). For example, in the severe obesity model, adults $\geq 65$ years (aRR: 
medRxiv preprint doi: https://doi.org/10.1101/2020.07.27.20161810; this version posted July 29, 2020. The copyright holder for this preprint

(which was not certified by peer review) is the author/funder, who has granted medRxiv a license to display the preprint in perpetuity.

This article is a US Government work. It is not subject to copyright under 17 USC 105 and is also made available for use under a CCO license.

4.6; 95\%CI: 3.6, 5.9), 45-64 years (aRR: 2.7; 95\%CI 2.1, 3.4) versus18-44 years; males versus

females (aRR: 1.4; 95\%CI: 1.1, 1.7); and non-Hispanic blacks (aRR: 4.7; 95\%CI: 3.8, 5.9) and other race/ethnicities (aRR: 3.5; 95\%: 2.8, 4.3) versus non-Hispanic whites had higher hospitalization rates. These associations were similar in models adjusting for any condition (Table 2) and number of conditions (Supplemental Table 3).

\section{DISCUSSION}

In this study utilizing two large multi-state surveillance systems to compare hospitalized cases with the community at risk, we found that increasing age, male sex, non-Hispanic black race/ethnicity, other race/ethnicities, and select underlying medical conditions were associated with a significantly greater risk for COVID-19-associated hospitalization relative to the nonhospitalized community-dwelling adult population. Among the underlying medical conditions studied, the magnitude of risk was greatest for severe obesity, chronic kidney disease, diabetes, obesity, and hypertension; each of these conditions was independently associated with approximately 3 or more times the risk of hospitalization after accounting for age, sex, and race/ethnicity. Among adults who tested positive for SARS-CoV-2 and sought care at health systems in Louisiana (19) and in New York City and Long Island (20), chronic kidney disease (20), obesity $(19,20)$, diabetes (20), and hypertension (20) were also found to be associated with increased odds of hospitalization (adjusted odds ratios ranging from 1.4 to 2.4) after accounting for age, sex, race/ethnicity $(19,20)$, and either the Charlson comorbidity index (19) or other select medical conditions (20). Our study extends the literature by quantifying the independent association of underlying medical conditions with hospitalization relative to the community population at risk.

Similar to other studies $(10,11,12,13,14)$, we found that hypertension, obesity, and diabetes were common among COVID-19-associated hospitalizations. In our study, prevalences 
medRxiv preprint doi: https://doi.org/10.1101/2020.07.27.20161810; this version posted July 29, 2020. The copyright holder for this preprint

(which was not certified by peer review) is the author/funder, who has granted medRxiv a license to display the preprint in perpetuity.

This article is a US Government work. It is not subject to copyright under 17 USC 105 and is also made available for use under a CCO license.

of all select underlying medical conditions was greatest among hospitalized COVID-19 patients compared to the COVID-NET catchment area and nationwide. Similar to nationwide estimates $(16,17)$, hypertension and diabetes were more common in middle and older aged adults with COVID-19-associated hospitalizations. Obesity was greatest in those 18-44 years old with COVID-19-associated hospitalizations, unlike nationwide estimates of obesity which are relatively similar across age groups (15). The prevalence of chronic kidney disease among adults with COVID-19-associated hospitalizations was similar to national estimates of chronic kidney disease calculated from albuminuria or serum creatinine measures (23). However, these estimates were higher than self-reported estimates from the COVID-NET catchment area and nationwide derived estimates from BRFSS. This difference may be in part due to medical abstraction vs. self-report ascertainment; an estimated $90 \%$ of adults with chronic kidney disease do not know they have it (23).

The magnitude of risk for COVID-19-associated hospitalization was lower for coronary artery disease, stroke, asthma, and COPD than for other medical conditions (e.g., hypertension) in our analysis. Our prevalence estimates of asthma and/or COPD (18\%) was similar to a study among adults who tested positive for SARS-CoV-2 (15\%), which found that asthma or COPD was not independently associated with risk for hospitalization (20). However, among hospitalized patients, coronary artery disease and COPD have both been found to be associated with intensive care unit admission, need for mechanical ventilation $(24,25)$ and mortality $(24,25$, 26).

We found that ages 45-64 years and 65+ years were independently associated with increased risk of hospitalization compared to ages 18-44 years after accounting for underlying medical conditions, sex, and race/ethnicity. Further, the magnitude of risk for hospitalization was greatest among adults 65 years and older, similar to other studies $(19,20)$. It is important to note 
medRxiv preprint doi: https://doi.org/10.1101/2020.07.27.20161810; this version posted July 29, 2020. The copyright holder for this preprint

(which was not certified by peer review) is the author/funder, who has granted medRxiv a license to display the preprint in perpetuity.

This article is a US Government work. It is not subject to copyright under 17 USC 105 and is also made available for use under a CCO license.

that the additional risk of age 65 years and older, and of age $45-64$ years, is relative to younger age (18-44 years) and should not be interpreted as absolute risk.

Males were $30 \%$ more likely to be hospitalized than females after accounting for age, race/ethnicity, and underlying medical conditions, similar to another study (20). Non-biological factors may lead to a greater proportion of males being hospitalized (e.g., increased exposure or delays in care seeking). Biological factors could include immune function suppression by testosterone compared to estrogen (27) or lower expression of angiotensin-converting enzyme 2 , a receptor that allows entry of SARS-CoV-2 into host cells, due to estrogen, potentially inhibiting severe clinical progression in females compared to males (28).

Over-representation of non-Hispanic black adults among hospitalized COVID-19 patients has been hypothesized to be due to the higher prevalence of underlying medical conditions (10, 19) such as hypertension, obesity, diabetes, and chronic kidney disease among the non-Hispanic black population $(15,16,17,23)$. While these conditions contributed to the total risk, we found that after accounting for underlying medical conditions, age, and sex, non-Hispanic black adults had four times greater risk of hospitalization than non-Hispanic white adults. Additionally, the magnitude of risk was similar across underlying medical conditions (aRR range: 4.0 to 4.7), suggesting that non-Hispanic black adults experience excess risk regardless of select underlying medical conditions. This association was also observed when controlling for the presence of any condition or the number of conditions. Black race was similarly associated with 3 times the risk of hospitalization in an Atlanta-based study (29). It has been suggested that non-Hispanic black adults might be more likely to be hospitalized due to increased exposures (e.g., related to occupation or housing) that could lead to increased incidence or more severe illness; differences in health care access or utilization; or systemic social inequities, including racism and discrimination $(30,31,32)$. However, we were unable to assess these factors with our data. 
medRxiv preprint doi: https://doi.org/10.1101/2020.07.27.20161810; this version posted July 29, 2020. The copyright holder for this preprint

(which was not certified by peer review) is the author/funder, who has granted medRxiv a license to display the preprint in perpetuity.

This article is a US Government work. It is not subject to copyright under 17 USC 105 and is also made available for use under a CCO license.

These factors may also explain similar findings of increased risk for hospitalization among other race/ethnicities.

Overall, these results have implications for clinical practice, as they identify high-risk patients who require closer monitoring and management of their chronic conditions during the ongoing COVID-19 pandemic. While specific underlying medical conditions studied imparted higher risk of hospitalization, we were unable to account for the duration of each condition or the degree to which each condition was controlled (e.g., glycemic control in diabetic patients). Nevertheless, clinicians might prioritize more aggressive control of underlying conditions with available treatments and encourage their patients to remain engaged in care for management of their chronic conditions while practicing preventive measures, such as wearing a cloth face covering and social distancing. These groups may also benefit from targeted preventative and therapeutic interventions.

\section{Limitations}

This study has several limitations. First, this analysis is based on data as of June 23, 2020 from COVID-NET, a surveillance system designed first to provide hospitalization rates. Additional data such as underlying medical conditions is reliant on medical chart abstraction; approximately $60 \%$ of the total hospitalized cases have yet to be abstracted for underlying medical condition. Thus, included cases represent a convenience sample of hospitalizations with underlying medical conditions, which may have resulted in biased estimates of risk. However, bi-weekly updates of this analysis over a 2-month period with the most recently available COVID-NET data (i.e., additional chart abstractions) suggests consistent estimates of the frequency and distribution of underlying conditions and resulting rate ratios. Second, these data did not include institutionalized adults. Third, estimates of risk are restricted to the COVID-NET catchment area; the interpretation of rate ratios as risk in this analysis assumes that risk of SARSCoV-2 infection is consistent across all groups. Fourth, we were unable to assess the association 
medRxiv preprint doi: https://doi.org/10.1101/2020.07.27.20161810; this version posted July 29, 2020. The copyright holder for this preprint

(which was not certified by peer review) is the author/funder, who has granted medRxiv a license to display the preprint in perpetuity.

This article is a US Government work. It is not subject to copyright under 17 USC 105 and is also made available for use under a CCO license.

of more granular race/ethnicity categories or co-occurring underlying health conditions due to small cell sizes from the COVID-NET catchment area; further investigation on both aspects is important. Fifth, COVID-NET likely under-ascertains COVID-19 cases as testing for SARSCoV-2 is performed at treating health care providers' discretion and is subject to clinician bias as well as variability in testing practices and capabilities across providers and facilities. However, this probably had minimal impact on our findings as hospitalized individuals are more likely to be tested than those in the community. Finally, we used BRFSS to obtain estimates for underlying medical conditions in the COVID-NET catchment area. As the ascertainment of underlying medical conditions was different across the two data systems (self-report vs. medical chart abstraction), we may have introduced bias in the rate ratio estimation. Self-reported diabetes (33) and hypertension (34) have high correlation with medical examination estimates. Self-report has been found to underestimate prevalence of chronic kidney disease (23) and obesity (34); thus, our rate ratios for these conditions may be overestimated.

\section{CONCLUSION}

This analysis quantifies associations of age, sex, race/ethnicity, and underlying medical conditions with risk of COVID-19 hospitalization relative to the non-hospitalized communitydwelling population. These data may aid clinicians in identifying individuals at higher risk for hospitalization who may require more vigilant care and monitoring, and groups that may benefit from preventive and therapeutic interventions. 
medRxiv preprint doi: https://doi.org/10.1101/2020.07.27.20161810; this version posted July 29, 2020. The copyright holder for this preprint

(which was not certified by peer review) is the author/funder, who has granted medRxiv a license to display the preprint in perpetuity.

This article is a US Government work. It is not subject to copyright under 17 USC 105 and is also made available for use under a CCO license.

\section{ACKNOWLEDGEMENTS}

Erin Parker, Jeremy Roland, Gretchen Rothrock (California Emerging Infections Program); Isaac

Armistead, Rachel Herlihy, Sarah McLafferty (Colorado Department of Public Health and

Environment); Paula Clogher, Hazal Kayalioglu, Amber Maslar, Adam Misiorski, Linda

Niccolai, Danyel Olson, Christina Parisi (Connecticut Emerging Infections Program, Yale

School of Public Health); Emily Fawcett, Katelyn Lengacher, Jeremiah Williams (Emerging

Infections Program, Georgia Department of Health, Veterans Affairs Medical Center,

Foundation for Atlanta Veterans Education and Research); Jim Collins, Kimberly Fox, Sam

Hawkins, Shannon Johnson, Libby Reeg, Val Tellez Nunez (Michigan Department of Health and

Human Services); Erica Bye, Richard Danila, Nagi Salem (Minnesota Department of Health);

Kathy Angeles, Lisa Butler, Cory Cline, Kristina G. Flores, Caroline Habrun, Emily B. Hancock,

Sarah Khanlian, Meaghan Novi, Erin C. Phipps (New Mexico Emerging Infections Program);

Alison Muse, Adam Rowe (New York State Department of Health); Sophrena Bushey, Maria

Gaitan, RaeAnne Kurtz, Marissa Tracy (Rochester Emerging Infections Program, University of

Rochester Medical Center); Ama Owusu-Dommey, Lindsey Snyder (Oregon Health Authority);

Katherine Michaelis, Kylie Seeley (Oregon Health \& Science University School of Medicine);

Kathy Billings, Katie Dyer, Melinda Eady, Anise Elie, Gaily Hughett, Karen Leib, Tiffanie

Markus, Terri McMinn, Danielle Ndi, Manideepthi Pemmaraju, John Ujwok (Vanderbilt

University Medical Center); Ryan Chatelain, Andrea George, Keegan McCaffrey, Jacob Ortega,

Andrea Price, Ilene Risk, Melanie Spencer, Ashley Swain (Salt Lake County Health

Department); Rainy Henry, Sonja Nti-Berko, Bob Pinner, Alvin Shultz (Emerging Infections

Program); Mimi Huynh, Monica Schroeder (Council for State and Territorial Epidemiologists);

Junling Ren, Bill Bartoli, Liegi Hu (CDC Division of Population Health, Northrup Grumman);

Gayle Langley, Melissa Rolfes, Carrie Reed (CDC). 
medRxiv preprint doi: https://doi.org/10.1101/2020.07.27.20161810; this version posted July 29, 2020. The copyright holder for this preprint

(which was not certified by peer review) is the author/funder, who has granted medRxiv a license to display the preprint in perpetuity.

This article is a US Government work. It is not subject to copyright under 17 USC 105 and is also made available for use under a CCO license.

\section{REFERENCES}

1. Johns Hopkins University \& Medicine. COVID-19 map. Baltimore, MD: Johns Hopkins University; 2020. https://coronavirus.jhu.edu/map.html

2. CDC. Coronavirus disease 2019 (COVID-19): cases in U.S. Atlanta, GA: US Department of Health and Human Services, CDC; 2020. https:// www.cdc.gov/coronavirus/2019-ncov/casesupdates/cases-in-us.html

3. Guan WJ, Ni ZY, Hu Y, et al. Clinical Characteristics of Coronavirus Disease 2019 in China. N Engl J Med. 2020;382(18):1708-1720.

4. Onder G, Rezza G, Brusaferro S. Case-Fatality Rate and Characteristics of Patients Dying in Relation to COVID-19 in Italy. JAMA. 2020 Mar 23. [Epub ahead of print]

5. COVID-19 Surveillance Group. Characteristics of COVID-19 patients dying in Italy: report based on available data on March 20th, 2020. Rome, Italy: Instituto Superiore Di Sanita; 2020. https://www.epicentro.iss.it/ coronavirus/bollettino/Report-COVID-2019_20_marzo_eng.pdf

6. Docherty AB, Harrison EM, Green CA, et al. Features of 20133 UK patients in hospital with covid-19 using the ISARIC WHO Clinical Characterisation Protocol: prospective observational cohort study. BMJ. 2020;369:m1985. Published 2020 May 22.

7. CDC COVID-19 Response Team. Severe outcomes among patients with coronavirus disease 2019 (COVID-19)—United States, February 12- March 16, 2020. MMWR Morb Mortal Wkly Rep 2020;69:343-6.

8. Stokes EK, Zambrano LD, Anderson KN, et al. Coronavirus Disease 2019 Case Surveillance - United States, January 22-May 30, 2020. MMWR Morb Mortal Wkly Rep. ePub: 15 June 2020.

9. CDC COVID-19 Response Team. Preliminary Estimates of the Prevalence of Selected Underlying Health Conditions Among Patients with Coronavirus Disease 2019 - United States, February 12-March 28, 2020. MMWR Morb Mortal Wkly Rep. 2020 Apr 3;69(13):382-386.

10. Garg S, Kim L, Whitaker M, et al. Hospitalization Rates and Characteristics of Patients Hospitalized with Laboratory-Confirmed Coronavirus Disease 2019 - COVID-NET, 14 States, March 1-30, 2020. MMWR Morb Mortal Wkly Rep. 2020 Apr 17;69(15):458-464.

11. Richardson S, Hirsch JS, Narasimhan M, et al. Presenting Characteristics, Comorbidities, and Outcomes Among 5700 Patients Hospitalized With COVID-19 in the New York City Area. JAMA. 2020 Apr 22. doi: 10.1001/jama.2020.6775. Online ahead of print.

12. Palaiodimos L, Kokkinidis DG, Li W, et al. Severe obesity, increasing age and male sex are independently associated with worse in-hospital outcomes, and higher in-hospital mortality, in a cohort of patients with COVID-19 in the Bronx, New York [published online ahead of print, 2020 May 16]. Metabolism. 2020;108:154262. 
medRxiv preprint doi: https://doi.org/10.1101/2020.07.27.20161810; this version posted July 29, 2020. The copyright holder for this preprint

(which was not certified by peer review) is the author/funder, who has granted medRxiv a license to display the preprint in perpetuity.

This article is a US Government work. It is not subject to copyright under 17 USC 105 and is also made available for use under a CCO license.

13. Cummings MJ, Baldwin MR, Abrams D, et al. Epidemiology, clinical course, and outcomes of critically ill adults with COVID-19 in New York City: a prospective cohort study [published online ahead of print, 2020 May 19]. Lancet. 2020;S0140-6736(20)31189-2. doi:10.1016/S01406736(20)31189-2

14. Buckner FS, McCulloch DJ, Atluri V, et al. Clinical Features and Outcomes of 105 Hospitalized patients with COVID-19 in Seattle, Washington [published online ahead of print, 2020 May 22]. Clin Infect Dis. 2020; ciaa632.

15. Hales CM, Carroll MD, Fryar CD, Ogden CL. Prevalence of obesity and severe obesity among adults: United States, 2017-2018. NCHS Data Brief, no 360. Hyattsville, MD: National Center for Health Statistics. 2020. https://www.cdc.gov/nchs/products/databriefs/db360.htm

16. Samanic CM, Barbour KE, Liu Y, et al. Prevalence of Self-Reported Hypertension and Antihypertensive Medication Use Among Adults - United States, 2017. MMWR Morb Mortal Wkly Rep. 2020;69(14):393-398.

17. Centers for Disease Control and Prevention. National Diabetes Statistics Report, 2020. Atlanta, GA: Centers for Disease Control and Prevention, U.S. Dept of Health and Human Services; 2020.https://www.cdc.gov/diabetes/pdfs/data/statistics/national-diabetes-statisticsreport.pdf

18. Gold JAW, Wong KK, Szablewski CM, et al. Characteristics and Clinical Outcomes of Adult Patients Hospitalized with COVID-19 - Georgia, March 2020. MMWR Morb Mortal Wkly Rep. 2020;69(18):545-550.

19. Price-Haywood EG, Burton J, Fort D, Seoane L. Hospitalization and Mortality among Black Patients and White Patients with Covid-19 [published online ahead of print, 2020 May 27]. N Engl J Med. 2020;10.1056/NEJMsa2011686.

20. Petrilli CM, Jones SA, Yang J, et al. Factors associated with hospital admission and critical illness among 5279 people with coronavirus disease 2019 in New York City: prospective cohort study. BMJ. 2020;369:m1966. Published 2020 May 22.

21. Kim L, Garg S, O’Halloran A, et al. Risk Factors for Intensive Care Unit Admission and Inhospital Mortality among Hospitalized Adults Identified through the U.S. Coronavirus Disease 2019 (COVID-19)-Associated Hospitalization Surveillance Network (COVID-NET) [published online ahead of print, 2020 Jul 16]. Clin Infect Dis. 2020; ciaa1012.

22. Centers for Disease Control and Prevention. Overview: BRFSS 2018. Atlanta, GA: US Department of Health and Human Services, Centers for Disease Control and Prevention; 2019. https://www.cdc.gov/brfss/annual_data/2018/pdf/overview-2018-508.pdf

23. Centers for Disease Control and Prevention. Chronic Kidney Disease in the United States, 2019. Atlanta, GA: US Department of Health and Human Services, Centers for Disease Control and Prevention; 2019. https://www.cdc.gov/kidneydisease/publications-resources/2019-nationalfacts.html. 
medRxiv preprint doi: https://doi.org/10.1101/2020.07.27.20161810; this version posted July 29, 2020. The copyright holder for this preprint

(which was not certified by peer review) is the author/funder, who has granted medRxiv a license to display the preprint in perpetuity.

This article is a US Government work. It is not subject to copyright under 17 USC 105 and is also made available for use under a CCO license.

24. Lippi G, Henry BM. Chronic obstructive pulmonary disease is associated with severe coronavirus disease 2019 (COVID-19). Respir Med. 2020;167:105941.

25. Alqahtani JS, Oyelade T, Aldhahir AM, et al. Prevalence, Severity and Mortality associated with COPD and Smoking in patients with COVID-19: A Rapid Systematic Review and MetaAnalysis. PLoS One. 2020;15(5):e0233147.

26. Wichmann D, Sperhake JP, Lütgehetmann M, et al. Autopsy Findings and Venous Thromboembolism in Patients With COVID-19 [published online ahead of print, 2020 May 6]. Ann Intern Med. 2020;M20-2003.

27. Spagnolo PA, Manson JE, Joffe H. Sex and Gender Differences in Health: What the COVID19 Pandemic Can Teach Us [published online ahead of print, 2020 May 8]. Ann Intern Med. 2020;10.7326/M20-1941.

28. La Vignera S, Cannarella R, Condorelli RA, et al. Sex-Specific SARS-CoV-2 Mortality: Among Hormone-Modulated ACE2 Expression, Risk of Venous Thromboembolism and Hypovitaminosis D. Int J Mol Sci. 2020;21(8):2948.

29. Killerby ME, Link-Gelles R, Haight SC, et al. Characteristics Associated with Hospitalization Among Patients with COVID-19 - Metropolitan Atlanta, Georgia, March April 2020. MMWR Morb Mortal Wkly Rep. 2020; 69: 790-794.

30. Wadhera RK, Wadhera P, Gaba P, et al. Variation in COVID-19 Hospitalizations and Deaths Across New York City Boroughs [published online ahead of print, 2020 Apr 29]. JAMA. 2020;e207197.

31. Yancy CW. COVID-19 and African Americans [published online ahead of print, 2020 Apr 15]. JAMA. 2020;10.1001/jama.2020.6548.

32. Bhala N, Curry G, Martineau AR, et al. Sharpening the global focus on ethnicity and race in the time of COVID-19 [published online ahead of print, 2020 May 8]. Lancet. 2020;S01406736(20)31102-8.

33. Schneider ALC, Pankow JS, Heiss G, et al. Validity and Reliability of Self-reported Diabetes in the Atherosclerosis Risk in Communities Study. American Journal of Epidemiology, 2012; 176 (8): 738-743

34. Van Eenwyk J, Bensley L, Ossiander EM, et al. Comparison of Examination-Based and SelfReported Risk Factors for Cardiovascular Disease, Washington State, 2006-2007. Prev Chronic Dis 2012;9:110321. 
medRxiv preprint doi: https://doi.org/10.1101/2020.07.27.20161810; this version posted July 29, 2020. The copyright holder for this preprint

(which was not certified by peer review) is the author/funder, who has granted medRxiv a license to display the preprint in perpetuity.

This article is a US Government work. It is not subject to copyright under 17 USC 105 and is also made available for use under a CCO license.

Figure 1. Analytic Population Flow Diagram, Coronavirus Disease 2019-Associated Hospitalization Surveillance Network, March 1-June 23, 2020

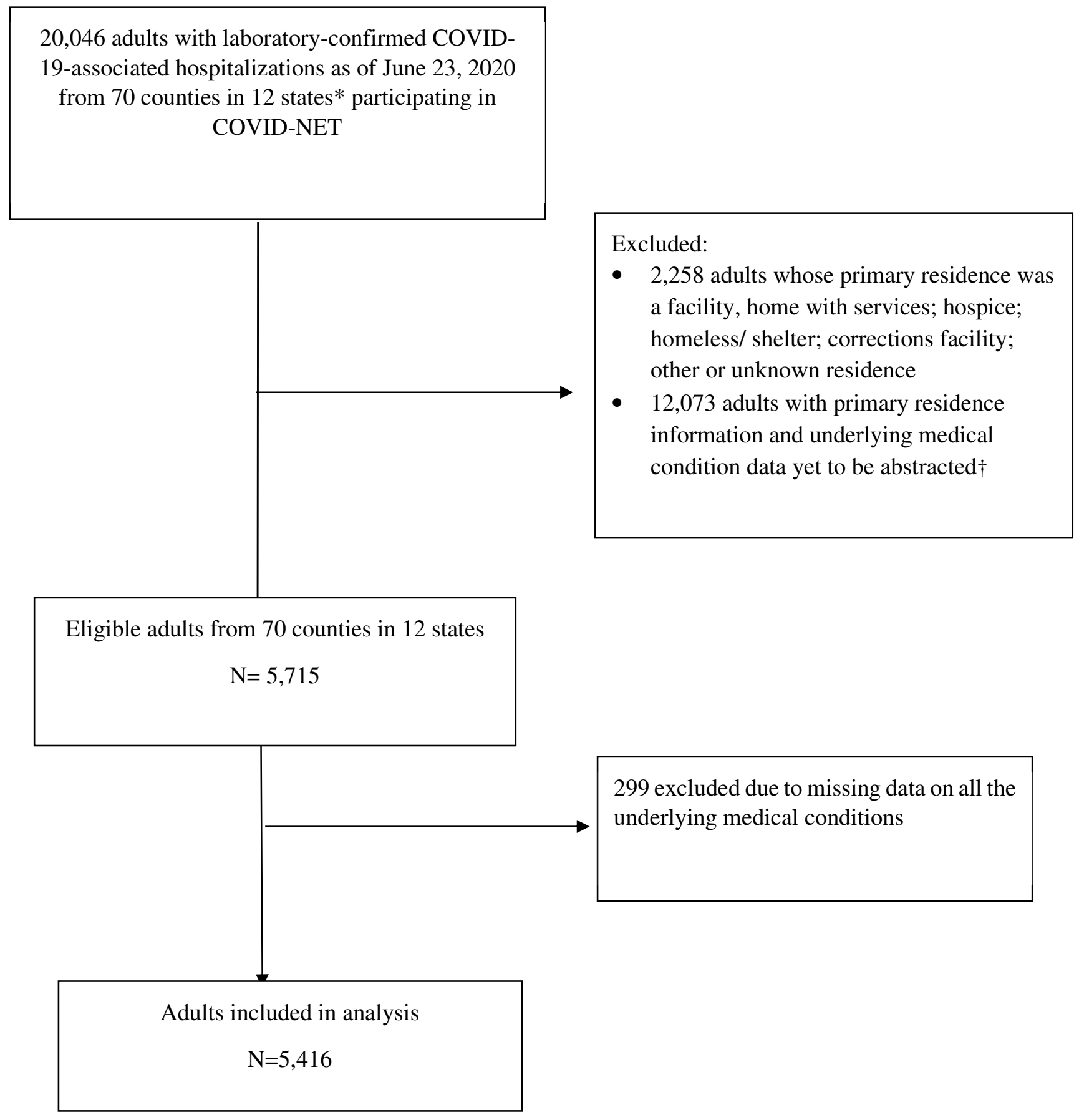

*California, Colorado, Connecticut, Georgia, Maryland, Michigan, Minnesota, New Mexico, New York, Oregon, Tennessee, and Utah.

$\dagger$ Additional data beyond the minimum required data elements (Case Identification Number, state, case type [pediatric vs. adult], age, admission date, sex, and SARS-CoV-2 test result [test type, test date, test result) to calculate age-stratified COVID-19-associated hospitalization rates may be subject to a time lag for submission to CDC. 
Table 1: Prevalence of Specific Underlying Medical Conditions among Community Dwelling Adults with COVID-19-associated Hospitalizations by Age, Sex, and Race/Ethnicity, COVID-NET* $(\mathrm{N}=5,416)$

\begin{tabular}{|c|c|c|c|c|c|c|c|c|c|}
\hline & $\begin{array}{l}\text { Overall } \\
\mathrm{N}=5,416\end{array}$ & $\begin{array}{c}\text { Age } \\
\mathbf{1 8 - 4 4} \\
n=1,60 \\
1(30 \%)\end{array}$ & $\begin{array}{c}\text { Age } \\
\mathbf{4 5 - 6 4} \\
\mathrm{n}=2,162 \\
(40 \%)\end{array}$ & $\begin{array}{c}\begin{array}{c}\text { Age } \\
\mathbf{6 5}+\end{array} \\
\mathrm{n}=1,653 \\
(31 \%)\end{array}$ & $\begin{array}{c}\text { Males } \\
n=2,847 \\
(53 \%)\end{array}$ & $\begin{array}{c}\text { Females } \\
n=2,569 \\
(47 \%)\end{array}$ & $\begin{array}{c}\text { Non- } \\
\text { Hispanic } \\
\text { White } \\
\mathrm{n}=1,758 \\
(34 \%)\end{array}$ & $\begin{array}{c}\text { Non- } \\
\text { Hispanic } \\
\text { Black } \\
\mathrm{n}=1,663 \\
(32 \%)\end{array}$ & $\begin{array}{c}\text { Other } \\
\text { Race/Ethnicity } \\
\text { Groups } \dagger \\
\mathrm{n}=1,798 \\
(34 \%)\end{array}$ \\
\hline $\begin{array}{l}\text { Presence of } \\
\text { Underlying } \\
\text { Medical } \\
\text { Condition } \$\end{array}$ & $\mathrm{n}(\%)$ & $\mathrm{n}(\%)$ & $\mathrm{n}(\%)$ & $\mathrm{n}(\%)$ & $\mathrm{n}(\%)$ & $\mathrm{n}(\%)$ & $n(\%)$ & $n(\%)$ & $\mathrm{n}(\%)$ \\
\hline Hypertension & $\begin{array}{l}2,658 \\
(49 \%)\end{array}$ & $\begin{array}{c}272 \\
(17 \%)\end{array}$ & $\begin{array}{l}1,146 \\
(53 \%)\end{array}$ & $\begin{array}{l}1,240 \\
(75 \%)\end{array}$ & $\begin{array}{l}1,469 \\
(52 \%)\end{array}$ & $\begin{array}{l}1,189 \\
(46 \%)\end{array}$ & $\begin{array}{c}956 \\
(55 \%)\end{array}$ & $\begin{array}{l}1,026 \\
(62 \%)\end{array}$ & $\begin{array}{c}594 \\
(33 \%)\end{array}$ \\
\hline $\begin{array}{l}\text { Coronary } \\
\text { Artery Disease }\end{array}$ & $\begin{array}{c}506 \\
(9 \%)\end{array}$ & $\begin{array}{c}11 \\
(1 \%)\end{array}$ & $\begin{array}{l}145 \\
(7 \%)\end{array}$ & $\begin{array}{c}350 \\
(21 \%)\end{array}$ & $\begin{array}{c}337 \\
(12 \%)\end{array}$ & $\begin{array}{c}169 \\
(7 \%)\end{array}$ & $\begin{array}{c}255 \\
(15 \%)\end{array}$ & $\begin{array}{l}155 \\
(9 \%)\end{array}$ & $\begin{array}{c}73 \\
(4 \%)\end{array}$ \\
\hline $\begin{array}{l}\text { History of } \\
\text { Stroke }\end{array}$ & $\begin{array}{c}227 \\
(4 \%)\end{array}$ & $\begin{array}{c}12 \\
(1 \%)\end{array}$ & $\begin{array}{c}70 \\
(3 \%)\end{array}$ & $\begin{array}{c}145 \\
(9 \%)\end{array}$ & $\begin{array}{c}134 \\
(5 \%)\end{array}$ & $\begin{array}{c}93 \\
(4 \%)\end{array}$ & $\begin{array}{c}79 \\
(5 \%)\end{array}$ & $\begin{array}{c}99 \\
(6 \%)\end{array}$ & $\begin{array}{c}41 \\
(2 \%)\end{array}$ \\
\hline Diabetes & $\begin{array}{l}1,793 \\
(33 \%)\end{array}$ & $\begin{array}{c}300 \\
(19 \%)\end{array}$ & $\begin{array}{c}798 \\
(37 \%)\end{array}$ & $\begin{array}{c}695 \\
(42 \%)\end{array}$ & $\begin{array}{c}984 \\
(35 \%)\end{array}$ & $\begin{array}{c}809 \\
(32 \%)\end{array}$ & $\begin{array}{c}528 \\
(30 \%)\end{array}$ & $\begin{array}{c}654 \\
(39 \%)\end{array}$ & $\begin{array}{c}548 \\
(31 \%)\end{array}$ \\
\hline Obesity & $\begin{array}{l}2,674 \\
(55 \%)\end{array}$ & $\begin{array}{c}801 \\
(63 \%)\end{array}$ & $\begin{array}{l}1,238 \\
(60 \%)\end{array}$ & $\begin{array}{c}635 \\
(41 \%)\end{array}$ & $\begin{array}{l}1,315 \\
(49 \%)\end{array}$ & $\begin{array}{l}1,359 \\
(62 \%)\end{array}$ & $\begin{array}{c}879 \\
(54 \%)\end{array}$ & $\begin{array}{c}929 \\
(60 \%)\end{array}$ & $\begin{array}{c}785 \\
(51 \%)\end{array}$ \\
\hline Severe Obesity & $\begin{array}{c}769 \\
(16 \%)\end{array}$ & $\begin{array}{c}312 \\
(25 \%)\end{array}$ & $\begin{array}{c}353 \\
(17 \%)\end{array}$ & $\begin{array}{c}104 \\
(7 \%)\end{array}$ & $\begin{array}{c}316 \\
(12 \%)\end{array}$ & $\begin{array}{c}453 \\
(21 \%)\end{array}$ & $\begin{array}{c}240 \\
(15 \%)\end{array}$ & $\begin{array}{c}329 \\
(21 \%)\end{array}$ & $\begin{array}{c}191 \\
(12 \%)\end{array}$ \\
\hline $\begin{array}{l}\text { Chronic Kidney } \\
\text { Disease }\end{array}$ & $\begin{array}{c}640 \\
(12 \%)\end{array}$ & $\begin{array}{c}54 \\
(3 \%) \\
\end{array}$ & $\begin{array}{c}201 \\
(9 \%)\end{array}$ & $\begin{array}{c}385 \\
(23 \%)\end{array}$ & $\begin{array}{c}387 \\
(14 \%)\end{array}$ & $\begin{array}{c}253 \\
(10 \%)\end{array}$ & $\begin{array}{c}206 \\
(12 \%)\end{array}$ & $\begin{array}{c}285 \\
(17 \%)\end{array}$ & $\begin{array}{l}125 \\
(7 \%)\end{array}$ \\
\hline Asthma & $\begin{array}{c}702 \\
(13 \%)\end{array}$ & $\begin{array}{c}211 \\
(13 \%)\end{array}$ & $\begin{array}{c}295 \\
(14 \%)\end{array}$ & $\begin{array}{c}196 \\
(12 \%)\end{array}$ & $\begin{array}{l}243 \\
(9 \%)\end{array}$ & $\begin{array}{c}459 \\
(18 \%)\end{array}$ & $\begin{array}{c}236 \\
(13 \%)\end{array}$ & $\begin{array}{c}276 \\
(17 \%)\end{array}$ & $\begin{array}{c}171 \\
(10 \%)\end{array}$ \\
\hline COPD & $\begin{array}{c}328 \\
(6 \%)\end{array}$ & $---\S$ & $\begin{array}{c}104 \\
(5 \%)\end{array}$ & $\begin{array}{c}219 \\
(13 \%)\end{array}$ & $\begin{array}{c}179 \\
(6 \%)\end{array}$ & $\begin{array}{c}149 \\
(6 \%)\end{array}$ & $\begin{array}{c}189 \\
(11 \%)\end{array}$ & $\begin{array}{c}102 \\
(6 \%)\end{array}$ & $\begin{array}{c}29 \\
(2 \%)\end{array}$ \\
\hline Any Conditionll & $\begin{array}{l}3,938 \\
(73 \%)\end{array}$ & $\begin{array}{c}978 \\
(61 \%)\end{array}$ & $\begin{array}{l}1,660 \\
(77 \%)\end{array}$ & $\begin{array}{l}1,300 \\
(79 \%)\end{array}$ & $\begin{array}{l}2,071 \\
(73 \%)\end{array}$ & $\begin{array}{l}1,867 \\
(73 \%)\end{array}$ & $\begin{array}{l}1,302 \\
(74 \%)\end{array}$ & $\begin{array}{l}1,338 \\
(80 \%)\end{array}$ & $\begin{array}{l}1,168 \\
(65 \%)\end{array}$ \\
\hline
\end{tabular}

CVD: Cardiovascular Disease; COPD: Chronic obstructive pulmonary disease

*COVID-NET: Coronavirus Disease 2019-Associated Hospitalization Surveillance Network (California, Colorado, Connecticut, Georgia, Maryland, Michigan,

Minnesota, New Mexico, New York, Oregon, Tennessee, and Utah), March 1-June 23, 2020 
$\dagger 197$ hospitalizations missing race/ethnicity information; Other race/ethnicity includes Alaskan Native/American Indian, Asian/Pacific Islander, Hispanic or Latino, multiple races

$\ddagger$ Variables with missing observations: Hypertension ( $\mathrm{n}=8 ; 0.1 \%)$; Coronary Artery Disease $(\mathrm{n}=11 ; 0.2 \%)$, History of Stroke $(\mathrm{n}=11 ; 0.2 \%)$, Diabetes $(\mathrm{n}=14 ; 0.3 \%)$, Obesity $(\mathrm{n}=518 ; 10 \%)$, Severe Obesity $(\mathrm{n}=518 ; 10 \%)$, Chronic Kidney Disease $(\mathrm{n}=16 ; 0.3 \%)$, Asthma $(\mathrm{n}=12 ; 0.2 \%), \operatorname{COPD}(\mathrm{n}=12 ; 0.2 \%)$

$\S$ Data suppressed due to small cell sizes

IIAny underlying medical condition excludes hypertension to align with 2018 BRFSS community estimates of underlying medical conditions; the most recent year of available BRFSS data for hypertension was 2017. 
Figure 2. Prevalence of Underlying Medical Conditions: Community Dwelling Adults with COVID-19-associated Hospitalizations,* COVID-NET Catchment Population, $\dagger$ and Nationwide BRFSS Estimates $\ddagger$

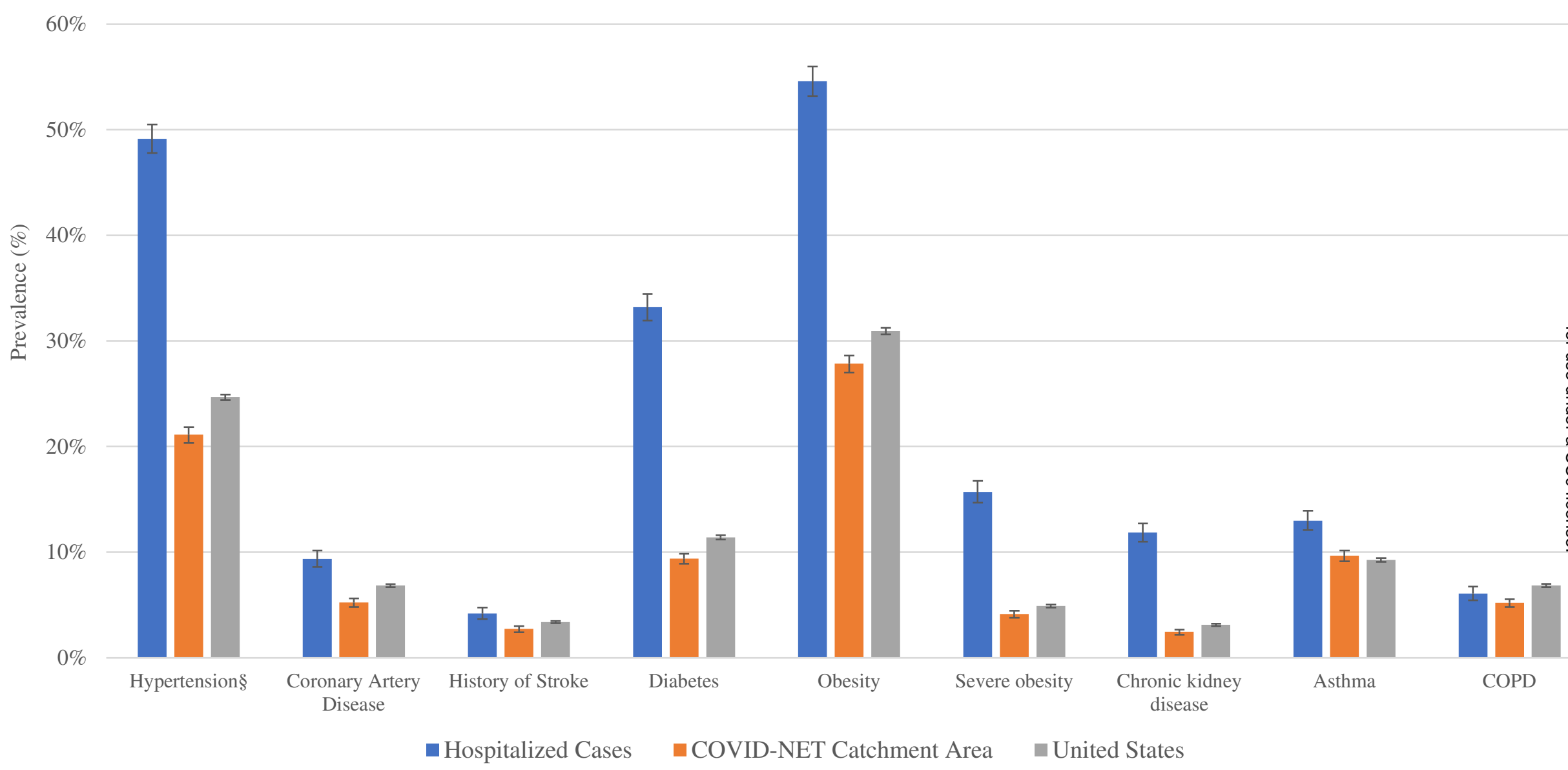

COPD: Chronic obstructive pulmonary disease

* Prevalence of underlying medical conditions among community-dwelling hospitalized cases from COVID-NET: Coronavirus Disease 2019-Associated

Hospitalization Surveillance Network (COVID-NET), March 1-June 23, 2020; error bars represent 95\% confidence interval surrounding estimates 
$\dagger$ Catchment population estimates from direct Behavioral Risk Factor Surveillance System estimates of underlying medical conditions aggregated from counties participating in COVID-NET, providing community level data on underlying health conditions, 2018; error bars represent 95\% confidence interval surrounding estimates

$\$$ Nationwide estimates from Behavioral Risk Factor Surveillance System (BRFSS), 2018; error bars represent 95\% confidence interval surrounding estimates

§Estimates for hypertension from COVID-NET Catchment Area and Nationwide BRFSS estimates are from 2017, the latest year of available data. 
Table 2. Unadjusted and Adjusted* Rate Ratios for COVID-19-Associated Hospitalizations by Underlying Condition among Community Dwelling Adults, COVID-NET, March 1-June 23, 2020

\begin{tabular}{|c|c|c|c|c|c|c|c|c|c|c|c|}
\hline & \multirow{2}{*}{$\begin{array}{c}\text { Unadjusted } \\
\text { RR } \\
(95 \% \mathrm{CI})\end{array}$} & \multicolumn{10}{|c|}{$\begin{array}{l}\text { Adjusted Models* } \\
\text { aRR }(95 \% \text { CI })\end{array}$} \\
\hline & & Hypertension & $\begin{array}{l}\text { Coronary } \\
\text { Artery } \\
\text { Disease }\end{array}$ & $\begin{array}{l}\text { History } \\
\text { of Stroke }\end{array}$ & Diabetes & Obesity & $\begin{array}{l}\text { Severe } \\
\text { Obesity }\end{array}$ & $\begin{array}{l}\text { Chronic } \\
\text { Kidney } \\
\text { Disease }\end{array}$ & Asthma & COPD & $\begin{array}{c}\text { Any } \\
\text { Condition }\end{array}$ \\
\hline $\begin{array}{l}\text { Age } 45-64 \\
\text { years } \dagger\end{array}$ & $2.0(1.8,2.1)$ & $\begin{array}{c}1.6 \\
(1.3,1.9)\end{array}$ & $\begin{array}{c}2.3 \\
(1.9,2.9)\end{array}$ & $\begin{array}{c}2.4 \\
(2.0,2.9)\end{array}$ & $\begin{array}{c}1.9 \\
(1.4,2.4)\end{array}$ & $\begin{array}{c}2.5 \\
(2.0,3.3)\end{array}$ & $\begin{array}{c}2.7 \\
(2.1,3.4)\end{array}$ & $\begin{array}{c}2.2 \\
(1.8,2.7)\end{array}$ & $\begin{array}{c}2.3 \\
(2.0,2.8)\end{array}$ & $\begin{array}{c}2.4 \\
(1.9,2.9)\end{array}$ & $\begin{array}{c}2.0 \\
(1.6,2.3)\end{array}$ \\
\hline Age $65+$ years $\dagger$ & $2.7(2.5,2.9)$ & $\begin{array}{c}2.2 \\
(1.7,2.7) \\
\end{array}$ & $\begin{array}{c}3.7 \\
(2.9,4.6)\end{array}$ & $\begin{array}{c}3.8 \\
(3.1,4.7)\end{array}$ & $\begin{array}{c}2.5 \\
(1.9,3.4)\end{array}$ & $\begin{array}{c}4.5 \\
(3.4,5.9)\end{array}$ & $\begin{array}{c}4.6 \\
(3.6,5.9)\end{array}$ & $\begin{array}{c}3.4 \\
(2.7,4.2) \\
\end{array}$ & $\begin{array}{c}3.8 \\
(3.1,4.6)\end{array}$ & $\begin{array}{c}3.8 \\
(3.0,4.8) \\
\end{array}$ & $\begin{array}{c}2.9 \\
(2.4,3.5)\end{array}$ \\
\hline Male $\div$ & $1.2(1.1,1.3)$ & $\begin{array}{c}1.2 \\
(1.1,1.4)\end{array}$ & $\begin{array}{c}1.2 \\
(1.03,1.4)\end{array}$ & $\begin{array}{c}1.2 \\
(1.1,1.4)\end{array}$ & $\begin{array}{c}1.2 \\
(0.98,1.5)\end{array}$ & $\begin{array}{c}1.4 \\
(1.1,1.7)\end{array}$ & $\begin{array}{c}1.4 \\
(1.1,1.7)\end{array}$ & $\begin{array}{c}1.2 \\
(1.02,1.4)\end{array}$ & $\begin{array}{c}1.2 \\
(1.1,1.5)\end{array}$ & $\begin{array}{c}1.2 \\
(1.03,1.5)\end{array}$ & $\begin{array}{c}1.2 \\
(1.1,1.4)\end{array}$ \\
\hline $\begin{array}{l}\text { Non-Hispanic } \\
\text { black } \S\end{array}$ & $3.9(3.7,4.2)$ & $\begin{array}{c}4.0 \\
(3.3,4.8)\end{array}$ & $\begin{array}{c}4.7 \\
(3.8,5.8)\end{array}$ & $\begin{array}{c}4.7 \\
(3.9,5.7)\end{array}$ & $\begin{array}{c}4.0 \\
(3.1,5.2)\end{array}$ & $\begin{array}{c}4.4 \\
(3.4,5.7)\end{array}$ & $\begin{array}{c}4.7 \\
(3.8,5.9)\end{array}$ & $\begin{array}{c}4.5 \\
(3.7,5.6)\end{array}$ & $\begin{array}{c}4.7 \\
(3.9,5.6)\end{array}$ & $\begin{array}{c}4.7 \\
(3.8,5.9)\end{array}$ & $\begin{array}{c}4.0 \\
(3.4,4.8)\end{array}$ \\
\hline $\begin{array}{l}\text { Other } \\
\text { race/ethnicity } \S\end{array}$ & $2.6(2.4,2.7)$ & $\begin{array}{c}3.5 \\
(2.9,4.2)\end{array}$ & $\begin{array}{c}3.3 \\
(2.7,4.0)\end{array}$ & $\begin{array}{c}3.3 \\
(2.7,4.0)\end{array}$ & $\begin{array}{c}3.0 \\
(2.3,3.9)\end{array}$ & $\begin{array}{c}3.5 \\
(2.8,4.5)\end{array}$ & $\begin{array}{c}3.5 \\
(2.8,4.3)\end{array}$ & $\begin{array}{c}3.3 \\
(2.7,4.1)\end{array}$ & $\begin{array}{c}3.2 \\
(2.7,4.0)\end{array}$ & $\begin{array}{c}3.3 \\
(2.7,4.1)\end{array}$ & $\begin{array}{c}3.3 \\
(2.8,4.0)\end{array}$ \\
\hline Hypertension & $3.6(2.3,5.8)$ & $\begin{array}{c}2.8 \\
(2.3,3.4)\end{array}$ & ----- & ----- & ----- & ----- & ----- & ----- & ----- & ----- & ----- \\
\hline $\begin{array}{l}\text { Coronary } \\
\text { Artery Disease }\end{array}$ & $1.9(0.7,4.7)$ & ----- & $\begin{array}{c}1.3 \\
(0.99,1.8)\end{array}$ & ----- & ----- & ----- & ----- & ----- & ----- & ----- & ----- \\
\hline $\begin{array}{l}\text { History of } \\
\text { Stroke }\end{array}$ & $1.6(0.4,6.1)$ & ----- & ---- & $\begin{array}{c}0.9 \\
(0.6,1.4)\end{array}$ & ----- & ----- & ----- & ----- & ----- & ----- & ----- \\
\hline Diabetes & $4.8(2.9,8.0)$ & ----- & ----- & ----- & $\begin{array}{c}3.2 \\
(2.5,4.1)\end{array}$ & ----- & ----- & ----- & ----- & ----- & ----- \\
\hline Obesity & $3.2(1.8,5.6)$ & ----- & ----- & ----- & ----- & $\begin{array}{c}2.9 \\
(2.3,3.5)\end{array}$ & ----- & ----- & ----- & ----- & ----- \\
\hline Severe obesity & $4.5(2.0,10.0)$ & ----- & ----- & ----- & ----- & ----- & $\begin{array}{c}4.4 \\
(3.4,5.7)\end{array}$ & ----- & ----- & ----- & ----- \\
\hline $\begin{array}{l}\text { Chronic kidney } \\
\text { disease }\end{array}$ & $5.3(2.4,12.1)$ & ----- & ----- & ----- & ----- & ----- & ----- & $\begin{array}{c}4.0 \\
(3.0,5.2)\end{array}$ & ----- & ----- & ----- \\
\hline Asthma & $1.4(0.6,3.1)$ & ----- & ----- & ----- & ----- & ----- & ----- & ----- & $1.4(1.1,1.7)$ & ----- & ----- \\
\hline COPD & $1.2(0.4,3.8)$ & ----- & ----- & ----- & ----- & ----- & ----- & ----- & ----- & $\begin{array}{c}0.9 \\
(0.7,1.4)\end{array}$ & ----- \\
\hline Any conditionll & $3.9(2.3,6.7)$ & ----- & ----- & ----- & ----- & ----- & ----- & ----- & ----- & ----- & $\begin{array}{c}3.2 \\
(2.7,3.8)\end{array}$ \\
\hline
\end{tabular}


aRR: adjusted Rate Ratios; CI: Confidence Interval; COPD: chronic obstructive pulmonary disease; COVID-NET: Coronavirus Disease 2019-Associated Hospitalization Surveillance Network; RR: Rate Ratio

*Each adjusted model for underlying medical condition includes the select underlying medical condition, age, sex, and race/ethnicity

$\dagger$ Reference group is $18-44$ years

$\ddagger$ Reference group is female

\$Reference group is non-Hispanic white

II Any underlying medical condition excludes hypertension to align with 2018 BRFSS community estimates of underlying medical conditions; the most recent year of

available BRFSS data for hypertension was 2017. 
Figure 3: Adjusted* Rate Ratios for COVID-19-Associated Hospitalization by Underlying Medical Condition, COVID-NET, March 1-June 23, 2020

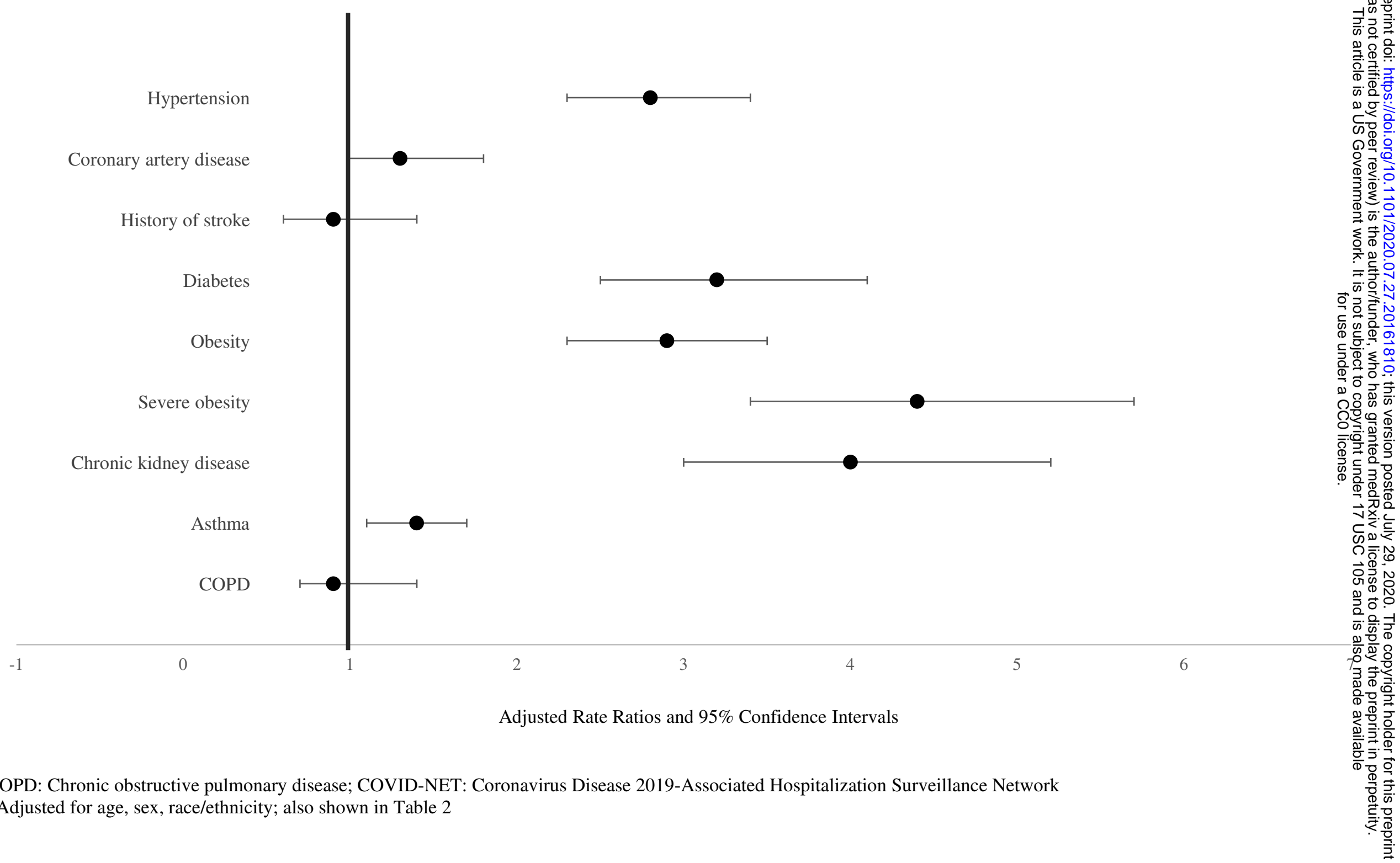

